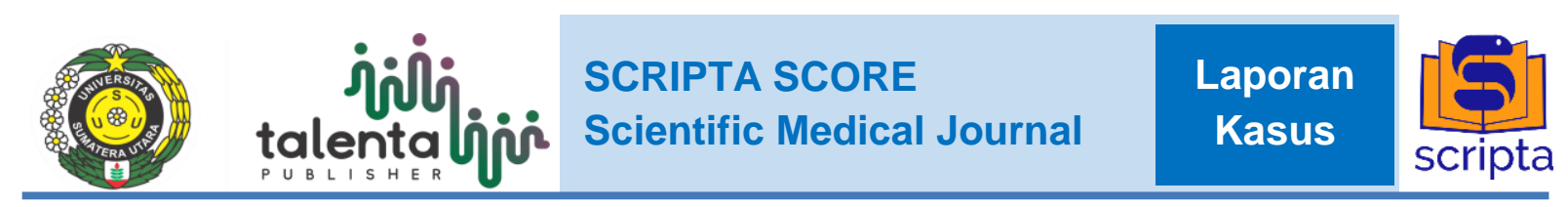

\author{
Refluks Laringofaring \\ Wita Aulia ${ }^{1}$ \\ ${ }^{l}$ Fakultas Kedokteran, Universitas Lampung, Bandar Lampung
}

\begin{abstract}
ABSTRAK
Refluks laringofaring adalah penyakit dimana terjadi aliran retrograde dari isi lambung ke laring dan faring kemudian cairan ini bersentuhan dengan saluran esofagus bagian atas. Penyakit ini berbeda dengan gastroesophageal reflux disease (GERD). Seorang laki-laki, usia 58 tahun seorang buruh datang dengan keluhan suara serak sejak 3 bulan yang lalu. Keluhan disertai dengan nyeri menelan dan nyeri tenggorokan yang memberat sejak 1 bulan ini. Pasien juga mengeluhkan suara sempat hilang timbul dalam 1 bulan ini. Pasien memiliki riwayat merokok dan mengaku bahwa menderita sakit maag sejak lama. Pemeriksaan fisik didapatkan tekanan darah 150/90 mmHg, nadi $102 \mathrm{x} / \mathrm{menit}$, pernapasan 20 x/menit, suhu $37,9^{\circ} \mathrm{C}$. Pada pemeriksaan penunjang Fiber Optic Laryngoscope (LFO), didapatkan epiglotis yang kaku serta aritenoid hiperemis bilateral dan edema minimal. Pada perhitungan skor RSI didapatkan hasil 18 dan skor RFS didapatkan hasil 9. Diagnosis pada pasien ini adalah refluks laringofaring. Penatalaksanaan pada pasien berupa medikamentosa yaitu Omeprazole tablet $40 \mathrm{mg} 2 \times 1$ tablet, Sukralfat syrup $3 \times 1$ sendok teh, dan $\mathrm{N}$-asetilsistein $3 \times 1$ tablet. Nonmedikamentosa dengan memberitahukan kepada pasien untuk jarak makan dan berbaring kurang lebih 2 jam, mengurangi konsumsi makanan berlemak, kopi, soda, alkohol, dan diet rendah asam, serta memberitahukan kepada pasien untuk memposisikan kepala sedikit lebih tinggi saat berbaring
\end{abstract}

Kata kunci: Fiber Optic Laryngoscope, refluks laringofaring, Reflux Finding Score, Reflux Symptom Index

\title{
ABSTRACT
}

Laryngopharyngeal reflux (LPR) is a disease in which retrograde flow occurs from the contents of the stomach to the larynx and pharynx and then this material is in contact with the upper esophagus. This disease is different from gastroesophageal reflux disease (GERD). A man, 58 years old laborer, came with complaints of hoarseness since 3 months ago. Complaints are accompanied by swallowing pain and throat pain that has worsened since 1 month. The patient also complained that the sound had disappeared within 1 month. The patient has a history of smoking and claims that he has had a longstanding heartburn. Physical examination found blood pressure of 150/90 $\mathrm{mmHg}$, pulse $102 \mathrm{x} / \mathrm{minute}$, breathing $20 \mathrm{x} /$ minute, temperature $37.9^{\circ} \mathrm{C}$. Investigations were done using the Fiber Optic Laryngoscope (LFO) and revealed a rigid epiglottis and bilateral hyperemic arytenoids and minimal edema. RSI score calculation results have been 18 and RFS score results have been 9. This pateint's diagnosis is Laryngopharyngeal reflux (LPR). Pharmacological management for this patient is Omeprazole $40 \mathrm{mg} 2 \times 1$ tablet, Sucralfate syrup $3 x 1$ teaspoon, and $N$-acetylcysteine $3 \times 1$ tablet. Nonpharmacological management is by telling the patient to give 2 hours time between eating and lying down. The patient is also told to reduce the consumption of fatty foods, coffee, soda, alcohol, and lowacid diets, and position the head slightly higher when lying down.

Keywords: Fiber Optic Laryngoscope, laryngopharyngeal reflux, Reflux Finding Score, Reflux Symptom Index

Received [14 Jan 2020] | Revised [16 Jun 2020] | Accepted [18 Jun 2020]

PENDAHULUAN
Refluks laringofaring merupakan
penyakit dimana terjadi aliran balik dari isi

lambung ke laring dan faring kemudian cairan ini bersentuhan dengan saluran pernafasan dan saluran pencernaan bagian atas. Penderita refluks laringofaring 
$\begin{array}{lcr}\text { memiliki } & \text { perbedaan } & \text { gejala dan } \\ \text { patofisiologi } & \text { dari } & \text { penderita } \\ \text { gastroesophageal } & \text { reflux } & \text { disease }\end{array}$ (GERD). ${ }^{[1]}$

Terdapat $50 \%$ orang dewasa menderita GERD dan diperkirakan 4-10\% dijumpai adanya kelainan laring kronis non spesifik di klinik THT yang berhubungan dengan penyakit refluks. Tidak ditemukan predileksi ras pada penyakit refluks. Namun prevalensi pria dibandingkan wanita meningkat yaitu 55\%:45\% dan meningkat pada usia lebih dari 44 tahun. ${ }^{[2]}$

\section{ILUSTRASI KASUS}

Seorang laki-laki, usia 58 tahun datang dengan keluhan suara serak sejak 3 bulan yang lalu. Awalnya, suara serak disertai dengan nyeri menelan yang makin memberat sejak 1 bulan ini. Pasien juga mengeluhkan suara sempat hilang timbul dalam 1 bulan ini. Sebelum keluhan tersebut muncul, pasien sempat mengalami demam \pm 3 hari dan batuk kering. Pasien mengaku tidak pernah berobat untuk keluhan ini. Tidak dijumpai keluhan pada telinga dan hidung. Pasien memiliki kebiasaaan sering telat makan dan sejak 2 tahun ini pasien baru berhenti merokok. Pasien juga mengaku bahwa menderita sakit maag. RSI (Reflux Symptom Index) yang ditanyakan saat anamnesis yaitu adanya suara serak (4), terdapat mukosa pada tenggorokan (2), kesulitan menelan (4), adanya batuk bermasalah (3), dan rasa panas, nyeri dada, gangguan pencernaan atau asam lambung yang muncul (5) sehingga didapatkan skornya 18.

Pada pemeriksaan fisik didapatkan tampak sakit ringan, kesadaran kompos mentis, tekanan darah 150/90 $\mathrm{mmHg}$, nadi $102 \mathrm{x} /$ menit, pernapasan $20 \mathrm{x} /$ menit, suhu $37,9{ }^{\circ} \mathrm{C}$. Status generalis kesan dalam batas normal. Status lokalis, pemeriksaan laringoskopi indirek didapatkan mukosa laring hiperemis dan tidak ada sekret, pada aritenoid dijumpai edema dan hiperemis. Epiglotis, valekula dan plika vokalis tidak ditemukan hiperemis dan edema,

Pada pemeriksaan penunjang dilakukan pemeriksaan Fiber Optic Laryngoscopy (LFO). Hasil dari pemeriksaan, seperti digambarkan pada Gambar 1, adalah sebagai berikut, Tonsil lingual: derajat 1 , tidak menutupi valekula. Valekula: tenang. Epiglotis: kaku. Aritenoid: hiperemis bilateral, edema minimal. Sinus piriformis: tenang. Plika ventrikularis: tenang. Plika vokalis :statis (tenang), dinamis (simetris, tertutup rapat, pergerakan baik, tidak ada yang tertinggal) hasil ini akan dimasukkan kedalam skor perhitungan diagnosis pada refluks laringofaring yaitu RFS (Reflux Finding Score).
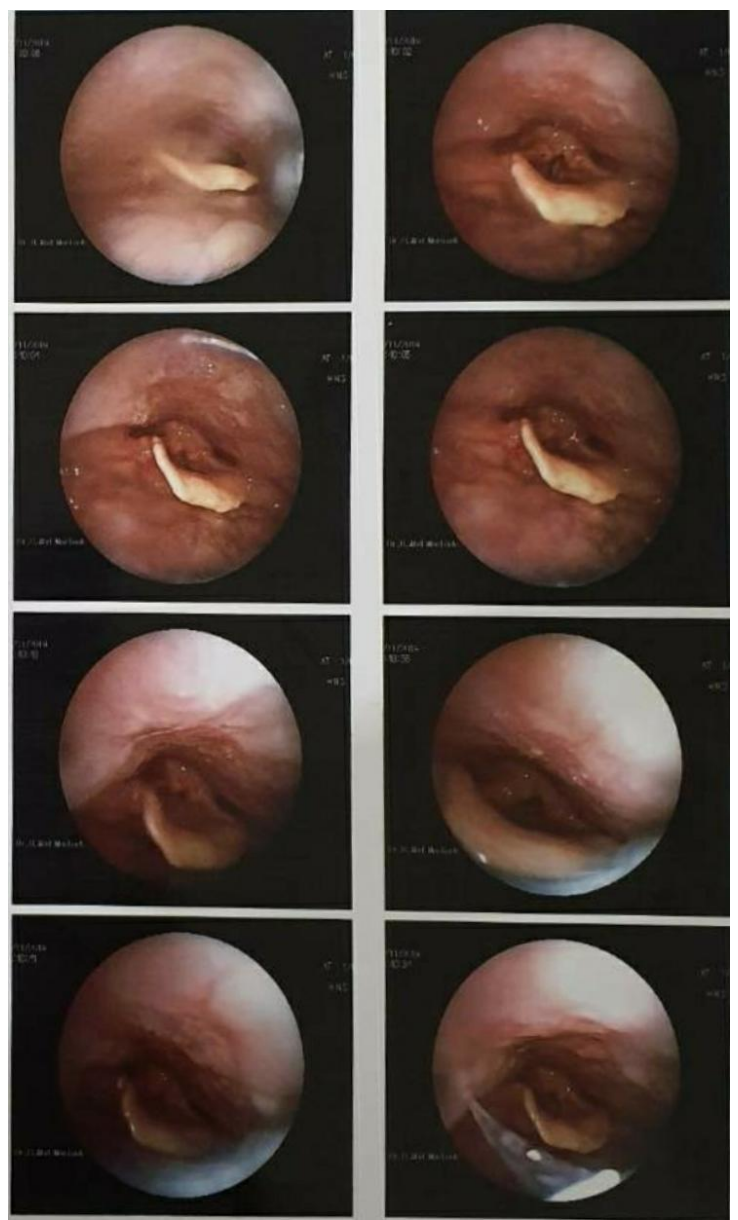

Gambar 1. Hasil pemeriksaan Fiber Optic Laryngoscopy (LFO)

Hasil RFS (Reflux Finding Score) yaitu 9. Adanya edema subglottis (2), hiperemis pada aritenoid (2), edema pita 
suara ringan (1), edema laring difus sedang (2), dan mukus endolaring (2).

Berdasarkan anamnesis, pemeriksaan fisik, dan pemeriksaan penunjang, maka diagnosis pada pasien ini adalah refluks laringofaring.

Penatalaksaan medikamentosa yang diberikan pada pasien berupa Omeprazole tablet $40 \mathrm{mg}$ $2 \times 1$, Sukralfat syrup $3 \times 1$ sendok teh, dan $\mathrm{N}$-asetilsistein tablet $3 \times 1$. Penatalaksanaan non-medikamentosa yang dilakukan adalah memberitahukan kepada pasien untuk berhenti makan 2 jam sebelum tidur, mengurangi konsumsi makanan yang berlemak, kopi, soda, alkohol, serta diet rendah asam, serta memberitahukan kepada pasien untuk memposisikan kepala sedikit lebih tinggi dari dada saat berbaring.

\section{PEMBAHASAN}

Pasien dengan refluks laringofaring akan mengalami keluhan pada daerah kepala dan leher, sedangkan pada GERD biasanya terdapat keluhan klasik seperti esophagitis dan rasa panas di dada. ${ }^{[1]}$ Penyebab refluks laringofaring adalah adanya refluks secara retrograde dari asam lambung atau isinya seperti pepsin, ke saluran esofagus atas dan menimbulkan cedera mukosa karena trauma langsung. Oleh karena hal tersebut, terjadi kerusakan silia yang menimbulkan tertumpuknya mukus, dan batuk kronis sehingga dapat menyebabkan iritasi dan inflamasi. ${ }^{[3]}$

Penyakit ini ditegakkan berdasarkan gejala klinis (Reflux Symptoms Index/RSI) dan pemeriksaan laring (Reflux Finding Score/RFS). Hal yang penting ditanyakan kepada pasien apakah ada perubahan suara terutama perubahan suara yang intermitten di siang hari. Jika ada keluhan ini, perlu ada kecurigaan ke arah penyakit refluks laringofaring. ${ }^{[1]}$ Terdapat 9 gejala refluks (Reflux Symptom Index/RSI) yang dapat digunakan untuk memperkirakan apakah ada gejala refluks laringofaring dan derajat sebelum dan sesudah terapi. Gejala yang sering muncul seperti suara serak, mendehem, penumpukan dahak di tenggorok atau postnasal drip, sukar menelan, batuk setelah makan, sulit bernafas atau tersedak, batuk yang sangat mengganggu, rasa mengganjal serta rasa panas di tenggorok, nyeri dada atau rasa asam naik ke tenggorok. Gejala tersering pada refluks laringofaring yaitu suara serak sekitar $71 \%$, batuk sekitar $51 \%$ dan rasa mengganjal di tenggorok (globusfaringeus) sekitar 47\%. Skor RSI adalah 0-45. Jika didapatkan skor $\geq 13$, maka curiga refluks laringofaring. Setelah dianamnesis untuk memastikan bahwa benar adanya penyakit, perlu dilakukan pemeriksaan penunjang berupa laringoskop fleksibel dan di masukkan ke dalam skor yaitu Reflux Finding Score (RFS). Skor dimulai dari 0 (tidak ada kelainan) dengan nilai maksimal 26. Jika nilai $\mathrm{RFS} \geq 7$ dengan tingkat keyakinan 95\%, dapat didiagnosis sebagai penyakit refluks laringofaring. Nilai ini juga dapat dengan baik memperkirakan efektifitas pengobatan pada pasien. ${ }^{[4]}$

Setelah dijelaskan skor pada ilustrasi kasus diatas pada pasien ini didapatkan bahwa skor RSI 18 terdapat kecurigaan penyakit refluks laringofaring. Kemudian dilakukan pemeriksaan berupa LFO untuk menghitung skor pada RFS didapatkan hasil skor 9 sehingga kesannya adalah refluks laringofaring. Penatalaksaan yang diberikan pada pasien yaitu golongan obat proton pump inhibitor (PPI) yang menjadi pilihan utama jika terdiagnosis dengan penyakit refluks laringofaring. ${ }^{[5]}$

\section{KESIMPULAN}

Refluks laringofaring adalah penyakit di mana adanya refluks pada asam lambung yang naik ke atas, sehingga mengiritasi saluran pada esofagus atas. Laki-laki usia di atas 44 tahun banyak yang menderita penyakit ini dengan faktor risiko meningkat pada orang dengan riwayat dispepsia/maag sebelumnya, merokok, dan alkoholik. 


\section{DAFTAR PUSTAKA}

[1] Diamond L. Laryngopharyngeal reflux-It's not GERD. J Am Acad PAs. 2005; 18(8):50-53.

[2] Hermani B, Abdurrachman H, Cahyono A. Kelainan laring. In: Soepardi EA, Iskandar N, Bashiruddin J, Restuti RD, editors. Buku ajar ilmu kesehatan telinga hidung tenggorok kepala \& leher. $7^{\text {th }}$ ed. Jakarta: Balai Penerbit Fakultas Kedokteran Universitas Indonesia; 2012. p. 23742.

[3] Koufman JA, Aviv JE, Casiano RR, Shaw GY. Laryngopharyngeal reflux: position statement of the committee on speech, voice and swallowing disorders of the American Academy of Otolaryngology-Head And Neck Surgery. Otolaryngol Head Neck Surg. $\quad 2002 ; 127(1): 32-35$. doi: 10.1067/mhn.2002.125760

[4] Belafsky PC, Postma GN, Koufman JA. The validity and reliability of the reflux finding score (RFS). Laryngoscope. 2001;111(8):1313-7. doi: $\quad 10.1097 / 00005537-200108000-$ $\underline{00001}$

[5] Karkos PD, Wilson JA. Empiric treatment of laryngopharyngeal reflux with proton pump inhibitors: a systematic review. Laryngoscope. 2006;116(1):144-8. doi: $\underline{10.1097 / 01 . m l g .0000191463 .67692 .3}$ $\underline{6}$ 